\title{
A regulamentação de queijos artesanais: algumas reflexões
}

\section{Some reflections on the regulation of artisan cheeses}

\author{
Andréa Carla Mendonça de Souza Paiva - Doutora em Nutrição. Universidade Federal Rural de Pernambuco \\ (UFRPE).Brasil-andreacarlams@gmail.com
}

\section{Palavras-chave: \\ Qualidade. Leite.}

Subsídios. Produtor
Keywords:

Quality. Milk. Subsidies. Producer.

\section{RESUMO}

As boas práticas de fabricação de alimentos consistem em requisitos básicos para a produção de alimentos seguros para o consumidor e, assim, envolve todos os elos da cadeia produtiva alimentícia. De acordo com a legislação, o leite é o produto oriundo de ordenha completa e ininterrupta, em condições de higiene, de vacas sadias, bem alimentadas e descansadas. Tendo em vista que a higiene foi e ainda é desafio fundamental para o produtor, a qualidade do leite assume destacada importância também sob o ponto de vista da Saúde Pública. A partir desse contexto, o presente artigo tem por objetivo apresentar um breve histórico sobre o sistema agroindustrial do leite, os serviços de inspeção sanitária no Brasil e a importância da regulamentação dos produtos artesanais. Para isso, aborda-se a apreensão dos queijos da chef Roberta Sudbrack no Rock in Rio, e a consequente atualização da Lei no 1.283, de 18 de dezembro de 1950, com a promulgação da Lei $n^{\circ} 13.680$ em 14 de junho de 2018. Embora a legislação facilitadora para a comercialização já existisse desde o ano de 2006, observa-se que faltou investimento do Estado em relação à estrutura do evento, o que dificultou os produtores artesanais a cumprirem com o exigido na lei. Assim, é importante que pesquisadores, chefs de cozinha e professores se unam para reivindicar os seus direitos quanto aos subsídios necessários para o produtor artesanal; a fim de garantir a estabilidade econômica, social e política da nação, a exemplo do que acontece na França e nos países da União Europeia.

\begin{abstract}
Good food manufacturing practices are basic requirements for the production of safe food for the consumer and involve all links in the food production chain. According to the legislation, milk is the product of complete and uninterrupted milking that is done under hygienic conditions and extracted from healthy cows, well fed and rested. Considering that hygiene was and still is the big challenge for the producer, the milk quality is also of vital importance, according to the point of view of Public Health. From this context, the purpose of this article is to present a brief report of the agroindustrial system of milk, sanitary inspection services in Brazil, and importance of artisanal products regulation. In this regard, it is discussed in this paper the seizure of Roberta Sudbrack's chef cheeses at Rock in Rio, and the consequent updating of Law $n^{\circ} 1.283$, of December 18,1950, with the promulgation of Law $n^{\circ}$ 13.680 , on June 14,2018 . Although the legislation to aid marketing exists since 2006 , there was a lack of State investment in relation to the event structure, which made difficult for artisanal producers to comply with what is required by law. It is therefore important that researchers, chefs, and teachers come together to claim their rights to get necessary subsidies for the artisanal producers, in order to guarantee the economic, social and political nation stability, as is the case in France and in the countries of the European Union.
\end{abstract}

Como citar este artigo

PAIVA, Andréa Carla Mendonça de Souza. A regulamentação de queijos artesanais: algumas reflexões. Revista Brasileira de Gastronomia, Florianópolis, v. 1, n. 1, p. 60-73, jul./dez. 2018. Disponível em: http://rbg.sc.senac.br/index.php/gastronomia/article/view/21. Acesso em: $d d \mathrm{~mm} a a$. 


\section{INTRODUÇÃO}

As Boas Práticas de Fabricação (BPF) consistem em um conjunto de requisitos básicos para a obtenção de produtos que não trazem riscos à saúde do consumidor. Além disso, elas possibilitam um ambiente de trabalho mais eficiente, otimizando todo o processo de produção; controlam as possíveis fontes de contaminação cruzada e garantem que o produto atenda às especificações de identidade e qualidade. De maneira geral, a segurança dos alimentos abrange dois setores: o quantitativo, o qual aborda a disponibilidade de nutrientes; e o qualitativo, o qual diz respeito à saúde do consumidor. Este princípio, inclusive, envolve todos os elos da cadeia produtiva de alimentos (GONÇALO, 2006).

A água e os alimentos de origem animal e vegetal, frescos ou processados, podem ser transmissores de vários microrganismos patógenos. O consumo desses alimentos e/ou de água contaminados pode causar doenças transmitidas por alimentos (DTA). Ao todo, são mais de 250 tipos de DTA relatadas; destas, a maioria se dá por infecções causadas por bactérias e suas toxinas, além de por vírus e parasitas. Já outras doenças podem ser causadas por toxinas naturais, como, por exemplo, das presentes em cogumelos venenosos, algas e peixes; ou por aquelas provenientes de produtos químicos prejudiciais ao homem, os quais contaminaram o alimento, como chumbo e agrotóxicos (REIS, 2010).

É importante destacar que, particularmente nos primeiros anos de vida do homem, o leite e seus derivados desempenham um papel nutricional importante para o homem, uma vez que fornecem nutrientes essenciais para o desenvolvimento do organismo. Segundo a Instrução Normativa $n^{\circ} 62$ (IN 62), entende-se por leite, sem outra especificação, o produto oriundo de ordenha completa e ininterrupta, feita em condições de higiene, de vacas sadias, bem alimentadas e descansadas (BRASIL, 2011). Um litro de leite por dia supre todas as necessidades proteicas de crianças com até seis anos de idade, e constitui mais de $50 \%$ do conteúdo de proteínas requisitado pelos adultos (FONSECA; SANTOS, 2000). É de se esperar, portanto, que exista uma grande preocupação em assegurar a integridade e a qualidade intrínseca do leite e dos produtos lácteos destinados ao consumo humano. Logo, a higiene foi e ainda é o grande desafio para o produtor. Nesse contexto, a qualidade do leite assume destacada importância também sob o ponto de vista da Saúde Pública. E é por isso que ele tem recebido atenção por parte de toda a cadeia produtiva, uma vez que o leite ainda apresenta problemas como a alta Contagem Bacteriana Total (CBT), a alta Contagem de Células Somática (CCS) e os baixos teores de sólidos (SANTOS, 2007).

A esse respeito, o problema é maior em relação à $\mathrm{CBT}$, que representa uma medida direta da contaminação do leite, sendo responsável pelas mais significativas não conformidades com o padrão estabelecido pela IN62 (MESQUITA et al., 2008). Os requisitos estabelecidos por essa normativa para a CBT e CCS são de no máximo $600.000 \mathrm{UFC} / \mathrm{mL}$ e $600.000 \mathrm{CS} / \mathrm{mL}$, respectivamente (BRASIL, 2011). Por outro lado, a CCS é utilizada mundialmente como um indicador de mastite. Em rebanhos, essa contagem é considerada uma ferramenta importante no controle da doença, uma vez que a infecção da glândula mamária tem sido reportada como a principal causa do aumento dos valores da CCS (LAEVENS et al., 1997).

Diante do contexto exposto, o presente artigo tem por objetivo apresentar algumas reflexões sobre o sistema agroindustrial do leite e os serviços de inspeção sanitária no Brasil, além de apontar a importância da regulamentação do queijo artesanal. 


\section{SISTEMA AGROINDUSTRIAL DO LEITE}

O Sistema Agroindustrial do Leite (SAG) no Brasil teve início no final do século XVIII, quando começou a decadência do mercado de café no Vale do Paraíba (MADALENA, 1997, apud JANUÁRIO, 2014). A falta de opção rentável na região fez com que a pecuária leiteira se tornasse uma opção. Segundo Januário (2014), o SAG no Brasil apresenta três fases distintas. A primeira tem início em 1945, quando o Estado passou a ter controle sobre a produção e comercialização do leite, ao regular o preço tanto ao produtor como ao consumidor. A esse respeito, a Lei $n^{\circ} 1.283$ de 18 de dezembro de 1950 regulamentou a inspeção industrial e sanitária dos produtos de origem animal. Por volta de 1952, determinou-se que todos os laticínios ficassem sob a inspeção do órgão Regulamentação da Inspeção Industrial e Sanitária de Produtos de Origem Animal (RIISPOA). O mesmo agente regulador determinou a classificação para o leite pasteurizado em três classes básicas: (1) Leite tipo A pasteurizado e embalado na fazenda; (2) Leite tipo B - resfriado na fazenda e processado em uma planta industrial; (3) Leite tipo C - resfriado em pontos de coleta e nas plantas de processamento, uma vez não tinha tratamento térmico na fazenda.

Na década de 70, foi instituída a lei federal que determinou a obrigatoriedade da inspeção sanitária para todas as empresas que atuavam com produtos de origem animal. Então, a inspeção passava a ser da competência do Serviço de Inspeção Federal (SIF). A nova imposição impactou na obrigatoriedade de investimentos tecnológicos por parte dos laticínios para que estes se mantivessem formalizados. Desse modo, esse momento se caracterizou como de rígido controle do Estado sobre o setor. O resultado foi um intenso movimento de fechamento de firmas e, ao mesmo tempo, crescimento da informalidade.

Já a segunda fase, ocorrida nas décadas de 80 e 90, se deu a partir da desregulamentação e do fim do controle do Estado, o que acarretou um incremento na competitividade do setor. Podese dizer que o início dos anos 90, na verdade, foi de intensa mudança no cenário do Brasil, com impactos importantes para o desenvolvimento do SAG, tais como:(a) o fim do controle de preços do leite, tanto para os produtores como para o varejo; (b) a estabilidade da moeda nacional com o Plano Real; (c) a abertura comercial e o início do Mercosul.

Ao final dos anos 90, foi criado o Plano Nacional de Qualidade do Leite (PNMQL), cujo objetivo era alavancar o setor leiteiro com base em padrões de qualidade; visando, ainda, a oferta de produtos com melhor nível sanitário para o mercado nacional e a ampliação da participação brasileira no mercado internacional. Esse plano foi oficialmente lançado pelo Governo Federal em maio de 1998, e regulamentado pela Instrução Normativa $n^{\circ} 51$ (IN 51) do Ministério da Agricultura, Pecuária e Abastecimento (MAPA), de 18 de setembro de 2002. Tem-se início, nesse momento, à terceira fase. A IN51 de 2002 fixou os padrões sanitários para a produção, identidade e qualidade dos diversos tipos de leite produzidos no país, bem como para a coleta e o transporte a granel do leite refrigerado. Ademais, desde julho de 2005, essa instrução está em vigor nas regiões sul, sudeste e centro-oeste (BRASIL, 2002). Também um dos pontos abordados pelo plano é a melhoria da fiscalização dos processos de industrialização de leite e derivados, processo este que no Brasil é realizado em três instâncias: federal, estadual e municipal.

Quando a IN51 de 2002 foi promulgada, já estava previsto que a adequação dos produtores e dos laticínios ao novo ambiente - de exigências mais rígidas de qualidade de produção demandaria a necessidade de mudanças dentro da fazenda e das relações entre produtores e laticínios. Por essa razão, foi estabelecido que as novas exigências de qualidade passariam a vigorar 
em 2005, ou seja, 3 anos após a sua publicação. E, por se tratar de um conjunto de exigências pioneiras, as quais eram totalmente desconhecidas para a grande maioria dos produtores e dos laticínios, os primeiros requisitos mínimos de qualidade do leite cru foram bastante tolerantes. Por exemplo, os primeiros critérios mínimos de qualidade do leite cru que começaram a vigorar a partir de 1 de julho de 2005 foram de CCS < 1 milhão expressas em CS/mL; e CBT < 1 milhão expressas em UFC/mL. Esses números deveriam ter uma redução gradual desses limites mínimos, tornando as exigências de qualidade cada vez mais rígidas com o passar do tempo. A IN 51 também previa que a cada 3 anos, após a entrada em vigor dos padrões mínimos de qualidade, fossem realizadas revisões que tornariam os critérios de CCS e CBT mais rígidos. Assim, o objetivo final dessa legislação seria colocar os critérios mínimos de qualidade do leite cru do Brasil em condições de igualdade aos de países da Europa e dos EUA.

Nos Estados Unidos, o primeiro limite legal de CCS, estabelecido em 1970, foi de 1.500 .000 células/mL. Em 1986, passou para 1.000.000 CS/mL; em 1991, ocorreu nova alteração para o valor, o qual vigora até hoje de 750.000 células $/ \mathrm{mL}$. É importante ressaltar que, embora o limite seja de $750.000 \mathrm{CS} / \mathrm{mL}$, a média de CCS de $98 \%$ dos rebanhos norte-americanos, em 2013, foi de 178.000 $\mathrm{CS} / \mathrm{mL}$. Além disso, apenas $1,5 \%$ dos rebanhos avaliados apresentaram CCS acima do limite estabelecido (NORMAN; WALTON; DÜRR, 2018)

Assim, era de se esperar que a criação da IN51 de 2002 resolveria todos os problemas de contaminação existentes na cadeia produtiva do leite. Contudo, tendo em vista que todo o processo de melhoria da qualidade levaria um prazo de 9 anos, conforme estabelecido pela nova legislação, apenas implantar uma Instrução Normativa não foi o suficiente para elevar a qualidade da produção leiteira. Outras ações conjugadas eram necessárias, como a reorganização do sistema de inspeção, a capacitação do produtor, a assistência técnica e, talvez, a estipulação do pagamento por qualidade. Tanto isso era necessário que, ao final de 2011, estimava-se que cerca de 30 a $40 \%$ das amostras de leite analisadas pela Rede Brasileira de Laboratórios de Controle da Qualidade do Leite (RBQL) estavam acima dos limites exigidos.

Em razão dos produtores não terem conseguido se adaptar às exigências no tempo estabelecido, a Instrução Normativa $n^{\circ} 51$ foi substituída pela IN 62, publicada pelo Ministério da Agricultura, Pecuária e Abastecimento (MAPA) em 29 de dezembro de 2011. A IN62 também regulamenta a produção, identidade, qualidade, coleta e o transporte do leite tipo A, leite cru refrigerado e leite pasteurizado. E, principalmente, definiu um novo cronograma para a adaptação gradativa dos produtores, além de ter mudado os limites de CBT e CCS. A nova legislação estabeleceu ainda: o controle sistemático de parasitas e mastites; o controle rigoroso de Brucelose e Tuberculose, com o objetivo de obter certificado de livre dessas doenças; e o fim dos leites tipo B e $C^{1}$.

Em 1 de julho de 2016, entrou em vigor os novos limites para a Contagem de Células Somáticas (CCS) e a Contagem Bacteriana Total (CBT) do leite. Contudo, as metas previstas pela IN 62 de 2011, mais uma vez, não foram alcançadas. Em razão disso, em 3 de maio de 2016, o MAPA publicou nova Instrução Normativa, a de número 7, a qual altera a IN 62/2011, estabelecendo novos prazos que foram estendidos por mais dois anos. Com isso, as regiões sul, sudeste e centro-oeste deverão se adequar às normas até 2018 , e as regiões norte e nordeste até 2019. Assim, a nova IN

${ }^{1}$ Em 1 de maio de 2005, o leite tipo C já havia sido extinto nas regiões centro-oeste, sul e sudeste. Já nas regiões Norte e Nordeste, isso se deu em 1 de julho de 2007, de acordo com o que já estava previsto na IN 52. 
modificou os limites básicos da CCS e da CBT, que caíram para $100 \mathrm{mil} \mathrm{CLS} / \mathrm{mL}$ e $400 \mathrm{mil}$ UFC/mL, respectivamente (cf. Quadro 1).

$\mathrm{Na}$ realidade, sempre que datas determinadas para mudanças se aproximam, surgem pressões protelatórias de várias origens. Tais pressões têm como principal argumento a necessidade de manter produtores na atividade, desenhando um risco social na qualidade do leite causado pelo seu maior refinamento. Essa constatação é facilmente verificável: é só observar os movimentos através de redes sociais, jornais, cooperativas etc. para notar que os produtores estão divididos quanto ao tema. Alguns são contrários às mudanças, misturando o assunto com questões relativas ao mercado e à formação de preços de leite. Outros demonstram decepção com a possibilidade de mais uma postergação dos limites (PITHAN; SILVA, 2016).

\begin{tabular}{|c|c|c|c|c|}
\hline \multirow{3}{*}{$\begin{array}{l}\text { Por propriedade } \\
\text { rural } \\
\text { ou por tanque } \\
\text { comunitário }\end{array}$} & $\begin{array}{c}\text { A partir de } \\
\text { 01/07/2008 até } \\
\text { 31/12/2011 } \\
\text { Regiões: } \\
\text { S/SE/CO }\end{array}$ & $\begin{array}{c}\text { A partir de } \\
\text { 01/01/2012 até } \\
\text { 30/06/2014 } \\
\text { Regiões: } \\
\text { S/SE/CO }\end{array}$ & $\begin{array}{c}\text { A partir de } \\
\text { 01/07/2014 até } \\
\text { 30/06/2018 } \\
\text { Regiões: } \\
\text { S/SE/CO }\end{array}$ & $\begin{array}{l}\text { A partir de } \\
\text { 01/07/2018 } \\
\text { Regiões: } \\
\text { S/SE/CO }\end{array}$ \\
\hline & $\begin{array}{l}\text { A partir de } \\
01 / 07 / 2019\end{array}$ & $\begin{array}{c}\text { A partir de } \\
01 / 07 / 2019\end{array}$ & $\begin{array}{c}\text { A partir de } \\
01 / 07 / 2019\end{array}$ & $\begin{array}{c}\text { A partir de } \\
01 / 07 / 2019\end{array}$ \\
\hline & $\begin{array}{c}\text { A partir de } \\
01 / 07 / 2010 \\
\text { até31/12/2012 } \\
\text { Regiões: N/NE }\end{array}$ & $\begin{array}{c}\text { A partir de } \\
01 / 07 / 2013 \\
\text { até30/06/2015 } \\
\text { Regiões: N/NE }\end{array}$ & $\begin{array}{c}\text { A partir de } \\
01 / 07 / 2015 \\
\text { até30/06/2019 } \\
\text { Regiões: N/NE }\end{array}$ & Regiões: N/NE \\
\hline $\begin{array}{l}\text { Contagem Padrão em } \\
\text { Placas (CPP) expressa } \\
\text { em UFC/mL } \\
\text { (mínimo } \\
\text { de } 1 \text { análise mensal } \\
\text { com média } \\
\text { geométrica sobre } \\
\text { o período de } 3 \\
\text { meses) }\end{array}$ & $\begin{array}{l}\text { Máximo de } \\
7,5 \times 10^{5}\end{array}$ & $\begin{array}{l}\text { Máximo de } \\
6,0 \times 10^{5}\end{array}$ & $\begin{array}{l}\text { Máximo de } \\
3,0 \times 10^{5}\end{array}$ & $\begin{array}{l}\text { Máximo de } \\
1,0 \times 10^{5}\end{array}$ \\
\hline $\begin{array}{l}\text { Contagem de Células } \\
\text { Somáticas (CCS) } \\
\text { expressa em CS/mL } \\
\text { (mínimode } 1 \text { análise } \\
\text { mensal com média } \\
\text { geométrica sobre o } \\
\text { período de } 3 \text { meses) }\end{array}$ & $\begin{array}{l}\text { Máximo de } \\
7,5 \times 10^{5}\end{array}$ & $\begin{array}{l}\text { Máximo de } \\
6,0 \times 10^{5}\end{array}$ & $\begin{array}{l}\text { Máximo de } \\
5,0 \times 10^{5}\end{array}$ & $\begin{array}{l}\text { Máximo de } \\
4,0 \times 10^{5}\end{array}$ \\
\hline
\end{tabular}

\section{OS SERVIÇOS DE INSPEÇÃO SANITÁRIA NO BRASIL}

O sistema brasileiro de inspeção de produtos de origem animal possui três esferas de atuação: federal, estadual e municipal. A Lei federal no. 1.283 de 1950 instituiu o Serviço de Inspeção Federal (SIF), que é o órgão responsável pela fiscalização da industrialização de produtos de origem animal em todo o país. Após quase 40 anos, em 1989, foi promulgada em âmbito federal a Lei no. 7.889 que instituiu o Serviço de Inspeção Estadual (SIE), delegando aos estados a obrigatoriedade 
da prestação dos serviços de inspeção sanitária e fiscalização dos produtos de origem animal (POA). Essa lei também instituiu o Serviço de Inspeção Municipal (SIM), o qual é baseado nos mesmos instrumentos legais que dão sustentação às esferas federal e estadual, o que não simplifica as normas pelo tipo de registro requerido. Assim, a diferença básica se dá no âmbito da comercialização.

Também em 1989, através de um decreto, houve a transferência compulsória de responsabilidade. Dito de outro modo, se a produção e a comercialização ocorrem no âmbito municipal, a competência de inspeção e fiscalização é de responsabilidade do município. No entanto, caso ocorram dentro do estado, a responsabilidade é estadual; e se ocorrerem entre estados e/ou no âmbito internacional, a responsabilidade passa a ser federal. Assim, os estabelecimentos registrados no Serviço de Inspeção Municipal (SIM) não podem comercializar fora do município de origem, bem como os registrados nos serviços estaduais não podem comercializar fora do estado de origem. Logo, ambos são competentes para realizar inspeções e fiscalizações nos estabelecimentos industriais. Já no transporte de produtos de origem animal, tais atividades cabem ao MAPA e às secretarias estaduais e municipais de agricultura. Quanto à fiscalização no varejo, esta compete à Secretaria de Saúde, por intermédio da Vigilância Sanitária, serviço que pode ser estadual ou municipal.

O Decreto $n^{\circ} 5.741$, de 30 de março de 2006, organiza o Sistema Unificado de Atenção à Sanidade Agropecuária (SUASA), que é um novo sistema de inspeção, disposto de forma unificada, descentralizada e integrada com: (1) a União (através do MAPA), que coordena o sistema como instância central e superior; (2) os estados e (3) o Distrito Federal, como instância intermediária; e (3) os municípios, como instância local, por meio de adesão voluntária. O objetivo maior seria garantir a saúde dos animais e a sanidade dos vegetais, a idoneidade dos insumos e dos serviços, e a identidade, qualidade e segurança higiênico-sanitária e tecnológica dos produtos finais destinados ao consumo. Assim, fazem parte do SUASA quatro subsistemas brasileiros de inspeção e fiscalização, a saber: (a) Sistema Brasileiro de Inspeção de Produtos de Origem Animal (SISBI-POA); (b) Sistema Brasileiro de Inspeção de Produtos de Origem Vegetal (SISBI-POV); (c) Sistema Brasileiro de Inspeção de Insumos Agrícolas; e (d) Sistema Brasileiro de Inspeção de Insumos Pecuários.

Em 20 de julho de 2011, a Instrução Normativa n³6 estabeleceu os requisitos para a adesão dos estados, do Distrito Federal e dos municípios, individualmente ou por meio de consórcios, ao Sistema Unificado de Atenção à Sanidade Agropecuária (SUASA), integrado pelo Sistema Brasileiro de Inspeção de Produtos de Origem Animal (SISBI-POA). De acordo com a legislação, as inspeções municipais e estaduais podem solicitar ao MAPA - que é responsável pela inspeção federal - a equivalência de inspeção, a qual deverá atender alguns critérios, caracterizando o SISBI-POA. Para obter tal equivalência, é necessário comprovar que o município e/ou o estado tem condições de avaliar a qualidade e a inocuidade dos produtos de origem animal com eficiência. Desse modo, se o estabelecimento possui o Serviço de Inspeção Estadual (SIE) ou o Serviço de Inspeção Municipal (SIM), continuará registrado no serviço municipal ou estadual, mas poderá comercializar em todo território nacional. No caso do SIM, o pedido de equivalência deverá vir do município.

Embora o SUASA tenha sido estabelecido desde o ano 2006, não houve adesão da maioria dos estados e municípios, pois muitos alegaram não ter recursos para o colocar em funcionamento, já que há a necessidade de uma estrutura mínima de fiscalização. O estado de Pernambuco, embora tenha uma forte tradição de produção de produtos artesanais, não aderiu ao SUASA de imediato. 
De acordo com dados disponíveis no site do MAPA, esse estado está em fase de adesão, contudo não há informações sobre a fase em que a adesão se encontra.

\subsection{A atualização da legislação}

Em 2017, durante o Rock in Rio, a chef Roberta Sudbrack teve $160 \mathrm{~kg}$ de queijo apreendidos pelas autoridades sanitárias. O produto não estava impróprio para o consumo, mas a comercialização estava irregular. Embora apresentasse o SIE do estado de Pernambuco, em razão de não possuir o registro do Serviço de Inspeção Federal (SIF), ela não poderia estar atuando no estado do Rio de Janeiro. A apreensão repercutiu nas redes sociais, em jornais de grande circulação nacional e internacional, além de programas de televisão. A discussão sobre a regulamentação veio à tona com posicionamentos de políticos e autoridades sobre a necessidade de atualizar a legislação criada em 1950. Em decorrência do evento, o Plenário da Câmara dos Deputados aprovou, em 26 de março de 2018, o Projeto de Lei ${ }^{\circ}$ 3.859/15. Finalmente, em 14 de junho de 2018, o Presidente Michel Temer sancionou a Lei ${ }^{\circ} 13.680$ - alterando a Lei $n$ 1.283 de 18 de dezembro de 1950 -que dispõe sobre o processo de fiscalização de produtos alimentícios de origem animal produzidos de forma artesanal.

Leia, a seguir, o que dispõem os artigos 1으, 2으, 10-A, além dos seus respectivos incisos, e 3응 da Lei $n^{\circ} 13.680$, de 14 de junho de 2018:

Art. 1을 Esta Lei altera a Lei no 1.283, de 18 de dezembro de 1950, para dispor sobre o processo de fiscalização de produtos alimentícios de origem animal produzidos de forma artesanal.

Art. 20 A Lei no 1.283, de 18 de dezembro de 1950, passa a vigorar acrescida do seguinte art. 10-A:

Art. 10-A. É permitida a comercialização interestadual de produtos alimentícios produzidos de forma artesanal, com características e métodos tradicionais ou regionais próprios, empregadas boas práticas agropecuárias e de fabricação, desde que submetidos à fiscalização de órgãos de saúde pública dos Estados e do Distrito Federal.

$\S 1$ 응 0 produto artesanal será identificado, em todo o território nacional, por selo único com a indicação ARTE, conforme regulamento.

$\S 2$ 2ㅇ $\mathrm{O}$ registro do estabelecimento e do produto de que trata este artigo, bem como a classificação, o controle, a inspeção e a fiscalização do produto, no que se refere aos aspectos higiênico-sanitários e de qualidade, serão executados em conformidade com as normas e prescrições estabelecidas nesta Lei e em seu regulamento.

$\S 3$ ㅇ As exigências para o registro do estabelecimento e do produto de que trata este artigo deverão ser adequadas às dimensões e às finalidades do empreendimento, e os procedimentos de registro deverão ser simplificados.

§ 40 A inspeção e a fiscalização da elaboração dos produtos artesanais com o selo ARTE deverão ter natureza prioritariamente orientadora.

$\S 5$ ㅇ Até a regulamentação do disposto neste artigo, fica autorizada a comercialização dos produtos a que se refere este artigo.

Art. 3으 Esta Lei entra em vigor na data de sua publicação.(BRASIL, 2018, s/p).

A nova lei determina no artigo 10-A que será permitida a comercialização interestadual de produtos alimentícios produzidos de forma artesanal, e apresenta o respeito aos métodos tradicionais. No entanto, há nela uma ressalva: "desde que estejam de acordo com as boas práticas agropecuárias e de fabricação, e submetidos à fiscalização de órgãos de saúde pública dos Estados e do Distrito Federal" (BRASIL, 2018). No que se refere à estrutura dos produtores de queijos artesanais, é muito comum que, nas regiões em que se concentra a produção pecuária, a fabricação 
de queijos de diferentes tipos faça parte de uma prática já enraizada, nascida da cultura alimentar local, cujo saber tradicional da fabricação do queijo é estendido à produção das queijarias. Esses estabelecimentos rurais, ao manter um modo de fazer tradicional, vivenciam um conflito com a imposição das normas regidas pela legislação específica para a produção de queijos. Essas normas, criadas pelos Estados Unidos na década de 1960, foram as precursoras no desenvolvimento de um sistema de controle sobre os processos, a matéria prima e o ambiente, constando dos regulamentos Hazard Analysis and Critical Control Point (HACCP). A criação desse sistema deu origem a mudanças no mercado de alimentos mundial, servindo como base para as normas sanitárias de vários países, tal como o Brasil.

Contudo, a partir do momento em que as exigências para a indústria começaram a ser ampliadas também para o mercado tradicional, iniciou-se um conflito entre a sociedade produtora local e os órgãos responsáveis pela implantação e controle da segurança e qualidade alimentar, a cargo da administração pública nas esferas federal, estadual e municipal. A falta de adequação das exigências até os dias atuais implica na informalidade das queijarias que, mesmo assim, continuam a fabricar seus produtos numa estrutura física que tenta, de diversos modos, adaptar-se às normas. Logo, na disputa de mercado entre as queijarias artesanais e as indústrias de laticínios, se sobressaem, principalmente na mídia, os aspectos relativos à qualidade dos queijos, a despeito da importância social e econômica da atividade para a sociedade rural. Especificamente no mercado de queijos no Brasil, existe um embate entre a tradicional forma de construir os espaços e produzir dos pequenos produtores de queijo e a imposição de adequar essas estruturas aos regulamentos descritos no HACCP.

Nesse contexto, a publicação da Lei n ${ }^{\circ} 13.680$ é de extrema importância, principalmente para a agricultura familiar; uma vez que, ao atualizar a legislação criada em 1950, poderá facilitar a produção e a inserção dos produtos no mercado formal - seja ele local, regional e/ou nacional -, quando inspecionados por órgãos de saúde pública dos Estados e do Distrito Federal. Outro ponto positivo da lei recai sobre os trâmites para a aprovação e regularização dos projetos agroindustriais que, com a descentralização do serviço de inspeção, poderá ser mais rápido e menos oneroso. Isso poderá impulsionar a implantação de novas agroindústrias no país.

\section{AS CONDIÇÕES DOS PRODUTORES DA FRANÇA E DO BRASIL: ALGUMAS REFLEXÕES}

A repercussão da apreensão do queijo no Rock in Rio suscitou muitos questionamentos e comparações com a França e com o queijo artesanal produzido naquele país. De antemão, é importante ressaltar que, embora tenham sido feitas essas comparações, o produtor do Brasil não possui as mesmas condições do produtor francês. No que diz respeito à alimentação das vacas, na França, é no pasto da região em que é elaborado o próprio queijo; e caso sejam usados grãos como o milho e a soja, a utilização deve ser moderada e sem transgênicos. Enquanto em países desenvolvidos ocorre um controle rigoroso sobre o uso de transgênicos e agrotóxicos, a alimentação das vacas no Brasil não apresenta uma padronização comum ao gado leiteiro, pois cada região adota a alimentação de acordo com as necessidades e condições existentes. Ainda em relação ao emprego de transgênicos e agrotóxicos, no Brasil, recentemente a Comissão Especial da Câmara dos Deputados analisou e aprovou o Projeto de Lei $n^{\circ} 6.299 / 2002$, que facilita o uso e a fiscalização de substâncias cancerígenas, classificando-as em aceitáveis e inaceitáveis. Isso significa que, embora tais produtos estejam fora de uso em outros países, caso o projeto seja aprovado no Plenário da 
Câmara, eles poderão ser utilizados e passarão a ser denominados de "fitossanitários" ao invés de agrotóxicos. Novamente, os interesses financeiros são colocados acima da saúde humana.

No que se refere aos subsídios, os produtores franceses são muito mais organizados, e o governo ajuda-os frequentemente a adequarem sua produção às normas existentes. Ora, eles não teriam como arcar com as modificações a curto prazo se não fosse o subsídio governamental fornecido pela União Europeia e pelo próprio governo francês. Se, por um lado, o governo financiou as instalações, houve uma contrapartida dos produtores que se preocuparam com a especialização da mão de obra. As linhas de crédito rural na Europa exigem cursos de habilitação no setor agropecuário, condições fitossanitárias ideais e pagamento de uma parte dos valores. A União Europeia, em particular a França, apresenta uma visão bem diferente quanto ao papel social e político do sistema agroindustrial. Por isso, eles fornecem subsídios para garantir a estabilidade econômica, social e política.

É importante ressaltar que há uma grande diferença entre o Brasil e a França. No Brasil, já existem linhas de crédito para essa finalidade no Banco do Brasil, fornecidas por meio do Programa Nacional de Fortalecimento da Agricultura Familiar (PRONAF) e da Empresa de Assistência Técnica e Extensão Rural do Governo do Distrito Federal (Emater). Entretanto, as taxas de juros ainda são elevadas para o patamar dos produtores do país, variando de $2,5 \%$ a 5,5\% ao ano, dependendo da atividade exercida. $O$ governo brasileiro precisa compreender que só haverá equilíbrio social e garantia da segurança alimentar se os produtores tiverem renda.

Já na França, os rebanhos não são grandes, ou seja, cada produtor tem em média 50 cabeças de gado. Existe um sistema de controle e rastreamento de cada animal por meio do uso de um brinco numerado, que é colocado desde o seu nascimento. Nesse brinco, o produtor informa, através do preenchimento de fichas padronizadas, quais remédios aplicou no animal, qual a alimentação realizada e a quantidade de leite produzida. As fichas são auditadas pelos fiscais do serviço veterinário que visitam regularmente cada fazenda sem nenhum custo adicional para o produtor. No Brasil, o sistema de identificação para a cadeia do leite se dá por rebanhos, através do Sistema Brasileiro de Identificação e Certificação de Bovinos e Bubalinos (SISBOV). Só que tal sistema é usado na prática somente por produtores de gado de corte para abastecer abatedouros que fazem parte do comércio internacional.

Apesar desse cenário brasileiro, já existe no país a Política Nacional de Assistência Técnica e Extensão Rural (PNATER) que consiste no programa de serviço público de assistência técnica e extensão rural. De maneira geral, a missão desse órgão é:

[...] participar na promoção e animação de processos capazes de contribuir para a construção e execução de estratégias de desenvolvimento rural sustentável, centrado na expansão e fortalecimento da agricultura familiar e das suas organizações, por meio de metodologias educativas e participativas, integradas às dinâmicas locais, buscando viabilizar as condições para o exercício da cidadania e a melhoria da qualidade de vida da sociedade. (IPA, 2018, s/p).

Só para citar um exemplo ilustrativo dessa discussão, vamos ler a descrição da PNATER trazida pelo site do Instituto Agronômico de Pernambuco (IPA): 
O IPA tem procurado adequar-se à realidade capacitando todos os seus extensionistas rurais e agentes de extensão rural para oferecer um serviço de qualidade aos agricultores familiares, com eficiência, eficácia e efetividade.

É importante registrar que a atual conjuntura nacional para esse serviço de Ater [Programa de Assistência Técnica e Extensão Rural] pública, possibilita um momento ímpar na história contemporânea da extensão rural brasileira e, consequentemente, para o IPA, por favorecer a consolidação do seu fortalecimento enquanto instituição de apoio ao desenvolvimento sustentável do agronegócio da agricultura familiar estadual. (IPA, 2018, $s / p)$.

Isso significa que, no que concerne o quantitativo da equipe técnica responsável pela extensão rural, descrita no portal do IPA (2018, s/p), no total há 21 membros para cumprir as metas do ATER (Programa de Assistência Técnica e Extensão Rural), as quais são descritas na Tabela 1 a seguir.

\begin{tabular}{|c|c|}
\hline AÇÕES & METAS \\
\hline Crédito rural & $\begin{array}{l}\text { Elaborar } 23.650 \text { certidões de aptidão. } \\
\text { Elaborar } 19.100 \text { projetos de crédito rural. }\end{array}$ \\
\hline Educação profissional & $\begin{array}{l}\text { Realizar } 318 \text { cursos para } 6.145 \text { participantes. } \\
\text { Realizar } 22 \text { seminários para } 1.490 \text { participantes. } \\
\text { Realizar } 216 \text { oficinas para } 3.672 \text { participantes. }\end{array}$ \\
\hline $\begin{array}{l}\text { Desenvolvimento local } \\
\text { sustentável }\end{array}$ & $\begin{array}{l}\text { Apoiar organizações de agricultores beneficiando } 651 \\
\text { associações e } 18 \text { cooperativas. } \\
\text { Apoiar } 93 \text { conselhos municipais. } \\
\text { Apoiar } 41 \text { comissões e outras organizações rurais. }\end{array}$ \\
\hline $\begin{array}{l}\text { Divulgação tecnológica em } \\
\text { propriedades e comunidades } \\
\text { rurais }\end{array}$ & $\begin{array}{l}\text { Realizar } 23 \text { dias de campo abrangendo } 1.700 \text { participantes. } \\
\text { Implantar } 18 \text { demonstrações de resultados abrangendo } 196 \\
\text { participantes. } \\
\text { Realizar } 202 \text { unidades demonstrativas abrangendo } 2.788 \\
\text { participantes. } \\
\text { Implantar } 221 \text { excursões envolvendo } 1.973 \text { participantes. } \\
\text { Implantar } 23 \text { unidades de teste e demonstração de resultados } \\
\text { abrangendo } 205 \text { participantes. }\end{array}$ \\
\hline $\begin{array}{l}\text { Técnicas de produção, de } \\
\text { organização e de } \\
\text { comercialização }\end{array}$ & $\begin{array}{l}\text { Prestar assistência técnica a } 89 \text { áreas de assentamento de } \\
\text { reforma agrária, totalizando } 3.338 \text { agricultores atendidos. } \\
\text { Prestar assistência técnica a oito áreas de quilombola, } \\
\text { totalizando } 260 \text { agricultores atendidos. } \\
\text { Prestar assistência técnica a sete áreas indígenas, totalizando } \\
540 \text { agricultores atendidos. }\end{array}$ \\
\hline $\begin{array}{l}\text { Incentivo ao } \\
\text { desenvolvimento de } \\
\text { atividades não-agrícolas }\end{array}$ & $\begin{array}{l}\text { Apoiar } 35 \text { projetos sobre produção artesanal abrangendo } 535 \\
\text { participantes. } \\
\text { Apoiar } 47 \text { projetos de produção agroindustrial abrangendo } 732 \\
\text { participantes. }\end{array}$ \\
\hline $\begin{array}{l}\text { Sistema de extensão rural } \\
\text { municipalizado (SERM) }\end{array}$ & $\begin{array}{l}\text { Implantação do SERM em } 60 \text { núcleos comunitários. } \\
\text { Implantar do SERM em } 32 \text { municípios. } \\
\text { Implantar do SERM tendo como foco } 10 \text { cadeias produtivas. }\end{array}$ \\
\hline $\begin{array}{l}\text { Ações complementares de } \\
\text { combate à seca }\end{array}$ & Contratar carros-pipas. \\
\hline
\end{tabular}

Tabela 1. Ações e metas do Programa de Assistência Técnica e Extensão Rural (ATER) do Instituto Agronômico de Pernambuco (IPA).

Fonte: IPA (2018) 
Apesar da descrição detalhada das ações e metas pelo IPA, o portal não estabelece o prazo para o cumprimento delas. Entretanto, é bem fácil constatar que o número de membros da equipe técnica descrito no portal não está em equilíbrio com o proposto que seria, por sua vez, "atender às dimensões locais" (idem). Logo, os dados do portal podem estar desatualizados; mesmo assim, o que está descrito deixa dúvidas se a equipe técnica conseguirá cumprir as ações e metas. No estado de Pernambuco, por exemplo, existem outros órgãos de colaboração ao produtor artesanal. A escolha de exemplificar com o IPA, no entanto, foi em razão do órgão ser vinculado às atividades de extensão rural com maior ênfase.

No que concerne à fiscalização, o país está diminuindo consideravelmente o número de fiscais agropecuários, tanto federais como estaduais. Enquanto outros países investem na fiscalização, o Brasil caminha em sentido contrário. Há, a esse respeito, um projeto de lei (o PL $\left.n^{\circ} 334 / 2015\right)$ que autoriza a terceirização da fiscalização dos produtos de origem animal, ou seja, permite que os estados e municípios credenciem empresas prestadoras de serviços de medicina veterinária para fazer a vistoria, a qual hoje é realizada apenas por profissionais do setor público (da união, dos estados e municípios). O objetivo desse PL, segundo o seu autor, o deputado Marco Tebaldi, é aumentar a competividade do setor e melhorar a economia nacional. Tal projeto já foi aprovado pela Comissão de Agricultura e Pecuária, Abastecimento e Desenvolvimento Rural (CAPADR) da Câmara dos Deputados, e atualmente está em análise pela Comissão de Cidadania e Justiça (CCJ).

O mais importante disso tudo é que a Organização das Nações Unidas para a Alimentação e a Agricultura ${ }^{2}$ (FAO) recomenda que os governos mantenham serviços veterinários básicos sob a sua responsabilidade, sendo a inspeção de carnes e alimentos um deles, pois considera que são melhor realizados pelo estado. O Brasil, mais uma vez, caminha em sentido contrário ás recomendações internacionais.

\section{CONCLUSÕES}

A repercussão da apreensão da chef Roberta Sudbrack e a sua importância na mídia nacional e internacional possibilitou que houvesse a atualização da legislação rapidamente. O PL supracitado já existia desde 2015, mas a pressão da mídia, efetivada pelo nome da chef, foi o que permitiu, de fato, a atualização da lei.

No contexto brasileiro, embora existisse uma legislação há certo tempo, a adesão ao Sistema Brasileiro de Inspeção de Produtos de Origem Animal (SISBI-POA) por parte dos órgãos fiscalizadores foi extremamente baixa. Isso porque, para a adesão, seria necessário um substancial conjunto de investimentos com relação à estrutura da fiscalização para atender as exigências da inspeção federal. Assim, é notável que não houve de fato investimentos adequados ao produtor de leite para atender aos requisitos mínimos de qualidade.

De modo geral, a regulamentação do produtor artesanal poderá melhorar a competitividade do setor produtivo. Além disso, tal regulamentação poderá trazer inúmeros benefícios para a segurança alimentar do consumidor final. Entretanto, é necessário uma série de investimentos do Estado com relação à estrutura da fiscalização; e, ainda, comprometimento com a educação do

\footnotetext{
${ }^{2}$ Food and Agriculture Organization of the United Nations
} 
produtor através de um programa eficiente de extensão rural, a fim de atender às exigências da inspeção estadual.

$E$, para que isso aconteça, é extremamente importante que a União, os estados e os municípios gerem esforços e investimentos em toda a cadeia de produção. Além disso, é fundamental a conjunção dos chefs de cozinha com todos os profissionais envolvidos e preocupados com a criação de políticas públicas efetivas por parte do Estado, sejam eles professores, médicos veterinários, pesquisadores etc.; todos unidos e fortes na busca efetiva de valorização do produtor artesanal de queijos. E, ainda, quando unidos, estes possam auxiliar na articulação dos produtores artesanais para que possam sobreviver diante da expansão das corporações nacionais e internacionais.

Por fim, destaca-se que o Estado brasileiro apresenta leis fortes, mas o sistema está completamente enfraquecido. O país possui uma enorme disparidade de sistemas de produção e um elevado número de produtores de leite. Logo, não é possível atender os requisitos mínimos de qualidade do leite e da produção adequada dos queijos artesanais apenas por meio de legislação. Ora, criam-se leis com muita facilidade no país, porém o Estado não realiza o investimento necessário para a adequação do produtor às normas exigidas. E esse cenário permanece desde a década de 50, período em que foram elaborados os primeiros programas de controle de qualidade.

\section{REFERÊNCIAS}

BRASIL. Lei $\mathrm{n}^{\circ}$ 13.680, de 15 junho de 2008. Altera a Lei $\mathrm{n}^{\circ}$ 1.283, de 18 de dezembro de 1950. Diário Oficial [da] República Federativa do Brasil, Brasília, DF, 14 junho de 2018. Disponível em: <http://www.planalto.gov.br/ccivil_03/_ato2015-2018/2018/Lei/L13680.htm>. Acesso em: 20 jun. 2018.

BRASIL. Ministério da Agricultura, Pecuária e Abastecimento. SISBI: sistema unificado de atenção à saúde agropecuária, sistema brasileiro de inspeção de produtos de origem animal. Secretaria de Defesa Agropecuária. Brasília: MAPA/ACS, 2011.

BRASIL. Instrução Normativa $n^{\circ}$ 7, de 3 maio de 2016. Altera a Instrução Normativa ${ }^{\circ}$ 62, de 29 de dezembro de 2011.Diário Oficial [da] República Federativa do Brasil, Brasília, DF, 4 de maio 2016. Disponível em:

ftp://ftp.saude.sp.gov.br/ftpsessp/bibliote/informe_eletronico/2016/iels.maio.16/lels81/U_IN-

MAPA-GM-7_030516.pdf>. Acesso em: 20 jun. 2018.

BRASIL. Ministério da Agricultura, Pecuária e Abastecimento. Instrução Normativa ${ }^{\circ}$ 62, de 20 de setembro de 2011. Diário Oficial [da] República Federativa do Brasil, Brasília, DF, 30 de dezembro de 2011. Seção 1, p.6.

BRASIL. Portaria $n^{\circ} 146$, de 7 de março de 1996. Aprova os regulamentos técnicos de identidade e qualidade dos produtos lácteos. Diário Oficial [da] República Federativado Brasil, Brasília, DF, 11 de março de 1996. Seção 1, p. 3977-3986.

FONSECA, L. F. L.; SANTOS, M. V. Qualidade do leite e controle de mastite. São Paulo: Lemos Editorial, 2000. 175 p. 
GONÇALO, E. Panorama da segurança de alimentos no Brasil e no mundo. [2006]. Disponível em: <http://www.cic.org.br/uploads/Rac/Seguran\%C3\%A7a_Alimentar_no_ Brasil_e_no_Mundo.pdf>. Acesso em: 16 jun. 2018.

INSTITUTO AGRONÔMICO DE PERNAMBUCO (IPA). Secretaria de Agricultura e Reforma Agrária. Governo do Estado de Pernambuco. s/d. Disponível em: <http://www.ipa.br/novo/\#>. Acesso em: 20 jun. 2018.

JANUÁRIO, E.de C. Mudanças institucionais e as relações entre produtores rurais e o segmento processador de leite no Brasil. 2014. Dissertação (Mestrado) - Universidade de São Paulo, São Paulo.

LAEVENS, H.; DELUYKER, H.; SCHUKKEN, Y.H. et al. Influence of parity and stage of lactation on the somatic cell count in bacteriologically negative dairy cows. Journal of Dairy Science, v.80, p.32193226, 1997.

MACHADO, R. L. P.; DUTRA, A. de S.; PINTO, M. S. V. Boas Práticas de Fabricação. Rio de Janeiro: Embrapa Agroindústria de Alimentos, 2015.

MADALENA, F. E. Sistema de reposição contínua do rebanho leiteiro com fêmeas F1 de BosTaurus x Bos Indicius no Brasil. ArchivosLatinoamericanos de Produción Animal, n. 5, p. 97-126, 1997.

MENDONÇA, A. A. V.; TOLEDO, A.M. Tipologias arquitetônicas das queijarias artesanais no semiárido alagoano. Labor \& Engenho, Campinas, v. 5, n. 4, p. 34-49, 2011. Disponível em: <https://periodicos.sbu.unicamp.br/ojs/index.php/labore/article/view/8634447>. Acesso em: 5 jun. 2018.

MESQUITA, A. J.; NEVES, R. B. S.; BUENO, V. F. F.; OLIVEIRA, A. N. A qualidade do leite na Região Centro Oeste e Norte do Brasil avaliada no Laboratório de Qualidade do leite - Goiânia - Goiás. In: Congresso Brasileiro de Qualidade do Leite, 3., 2008, Recife. Anais... Recife: CCS Gráfica e Editora, 2008. v. 1, p. 11-23.

NORMAN, H. D.; WALTON, L. M.; DÜRR, J. Somatic cell counts of milk from Dairy Herd Improvement herds during. Council on Dairy Cattle Breeding (CDCB), Beltsville, p. 2-18, s/d. Disponível em:<https://queries.uscdcb.com/publish/dhi/current/sccrpt.htm>. Acesso em: 4 jun. 2018.

PITHAN E SILVA, R.de O. Sobre a Nova Instrução Normativa $n^{\circ} 7$ para a Qualidade do Leite. Análises e Indicadores do Agronegócio, São Paulo, v. 11, n. 7, 2016.

REIS, C. B. M.d. Avaliação da contagem de células somáticas do leite como indicador da ocorrência da mastite em vacas Gir. 2010. Dissertação (Mestrado) - Universidade de São Paulo, São Paulo.

SANTOS, M. V.; FONSECA, L. F. L. Estratégias para controle de mastite e melhoria da qualidade do leite. 1. d. Barueri: Editora Manole, 2007. 314 p.

SANTOS, M. V.Padrões mínimos de qualidade do leite: é necessária uma nova revisão da IN 62?MilkPoint,s/p, 28 ago. 2014. Disponível em: <https://www.milkpoint.com.br/colunas/marco- 
veiga-dos-santos/padroes-minimos-de-qualidade-do-leite-e-necessaria-uma-nova-revisao-da-in62-205597n.aspx>. Acesso em: 6 jun. 2018.

TEODORO, V. A. M.; SILVA, J. F.; PINTO, M. S. A. Evolução da legislação no setor de lácteos no Brasil. Informe Agropecuário, Belo Horizonte, v. 28, n. 238, p. 14-21, 2007. 